\title{
Intracisternal A-Particles in Genetically Diabetic Mice: Identification in Pancreas and Induction in Cultured Beta Cells
}

\author{
E. H. Leiter and H. G. Bedigian \\ The Jackson Laboratory, Bar Harbor, Maine, USA
}

Summary. Sucrose density gradient analysis of purified pancreatic homogenates from glycaemic $\mathrm{C} 57 \mathrm{BL} / \mathrm{Ks}$ diabetes $(\mathrm{db} / \mathrm{db})$ mice and their normoglycaemic controls have revealed the presence in the diabetics of increased $\mathrm{Mg}^{++}$-dependent RNAdirected DNA polymerase activity sedimenting with a density of approximately $1.21 \mathrm{~g} / \mathrm{cm}^{3}$. Electron microscopy revealed that this fraction contained typical intracisternal A-particles. Purified cultures of pancreatic islet cells from 4-7 day old postnatal "misty diabetic" mice and normal siblings were established and then maintained in Eagle's minimal essential medium without serum. Under these conditions, the presence of intracisternal A-particles in beta cells of both mutant and control genotypes was very rare. No change in numbers of intracisternal A-particles was seen after 2-4 days of incubation in Dulbecco's-modified minimal essential medium containing $5.5 \mathrm{mmol} /$ 1 glucose. However, when the glucose concentration of Dulbecco's medium was elevated to $16.5 \mathrm{mmol} / 1$, ultrastructural changes specific to the beta cell population occurred that were reminiscent of those alterations observed in situ. Intracisternal A-particles were commonly seen in cultured beta cells showing hypersecretion-stress morphology. Since equal numbers of intracisternal A-particles were present in cultured beta cells from normal and mutant mice, it was concluded that the $\mathrm{db}$ gene itself was not required for intracisternal A-particle expression. The cell culture results suggest that elevated intracisternal A-particle activity observed in vivo may be produced directly or indirectly by the ambient high blood glucose levels characteristic of this mutant.

Key words: Intracisternal A-particle, pancreatic islet cell culture, C57BL/Ks diabetes mice, RNA-directed DNA polymerase, beta cell, virus induction.
Bernhard [3] proposed a classification for the diverse group of RNA virus known collectively as retroviruses. According to this system, retroviruses are designated as type $\mathrm{A}$, type $\mathrm{B}$, or type $\mathrm{C}$ primarily upon morphological criteria. Type $\mathrm{A}$ viruses have never been found extracellularly, nor have they been shown to be infectious as have type $B$ and type $C$ viruses. Type A virus does possess biochemical similarities to other members of the retroviridae, namely [1] a high molecular weight RNA and [2] an enzyme referred to as RNA-directed DNA polymerase which is able to synthesise a DNA transcript of the intrinsic viral RNA genome. Although this enzymatic reaction is shared by all retroviruses, differences in reaction conditions exist. Thus type A-polymerase shows optimal activity with $\mathrm{Mg}^{++}$ion as a cofactor, while type C-polymerase has greater affinity for $\mathrm{Mn}^{++}$ion [17]. Additionally, differences in viral structural proteins unique to each member permits discrimination among the groups by serological and physical means [19]. In C57BL/KsJ (BL/Ks) mice, the presence of the gene, diabetes $(\mathrm{db})$, in homozygous condition produces a severe diabetes syndrome culminating in necrosis and atrophy of the insulin-producing B cells $[8,21,22]$. Ultrastructural studies [22] of islet cells in the pancreas of $\mathrm{db} / \mathrm{db}$ mice with established hyperglycaemia (blood glucose $200-400 \mathrm{mg} / \mathrm{dl}$ ) revealed the presence of "virus-like bodies" which were not commonly detected in islet cells of normoglycaemic controls. These spherical particles, observed within cisternae of the rough endoplasmic reticulum (RER), were noted in both intact and degenerating B cells, as well as in intraislet exocrine cells and occasionally in A cells [22]. Although the size and structure reported for these "virus-like bodies" were consistent for their classification as retroviruses, specifically, intracisternal type A-particles, they have not yet been isolated and character- 
ised as such. Thus, one purpose of this study was to determine whether. or not these particles displayed some characteristic biochemical properties of retroviruses. A second was to determine the role played by the db gene in the induction of these particles inside B cells. Since the appearance of these particles in vivo was almost always noted in $B$ cells of $d b$ / $\mathrm{db}$ mice at advanced or terminal stages of the diabetes syndrome, coincident to $\mathrm{B}$ cell degeneration, it was of interest to evaluate whether expression of the $\mathrm{db}$ gene itself was required for particle induction, or whether the appearance of these structures was a response to the diabetic milieu (sustained hyperglycaemia, transient hyperinsulinaemia). The availability of a BL/Ks breeding stock carrying the recessive coat colour gene misty (m) in tight linkage on Chromosome 4 with the recessive gene, diabetes $(\mathrm{db})$, has enabled us to distinguish $\mathrm{db} / \mathrm{db}$ from normal littermate sibs four days post-partum [9]. Thus, we have been able to establish highly-purified pancreatic islet cell cultures from these pre-diabetic mice to assess the relative contributions of genotype and in vitro environment to the induction of these particles.

\section{Experimental Procedures}

\begin{abstract}
Mice
Pre-weaning C57BL/KsJ $\mathrm{m} \mathrm{db} / \mathrm{m}$ db (misty diabetic) mice of both sexes were produced at the Jackson Laboratory and were used to establish pancreatic cell cultures between 4-7 days after birth. Adult male C57BL/KsJ diabetes mice and controls were obtained from the Animal Resources Colony, Jackson Laboratory, and were used at between 12 and 16 weeks of age for whole pancreatic homogenate studies. Mice were allowed free access to water and food (diet 96W, Emory Morse Company, Old Guilford, Conn.).
\end{abstract}

\section{Preparation and Analysis of Subcellular Fractions}

Intracisternal A-particles were isolated from equal 1-2 $\mathrm{g}$ (wet weight) amounts of pancreases of normal and diabetic mice by the method of Kuff et al. [18]. Aprotonin (Trasylol, FBA Pharmaceuticals, N. Y., N. Y.) was added at 0.1 volume during homogenization to inhibit proteolytic activity. The presence of intracisternal A-type viral activity in these isolates was analyzed by determining the density at which particulate $\mathrm{Mg}^{++}$-requiring RNA-directed DNA polymerase reached equilibrium during density gradient centrifugation. $0.2 \mathrm{ml}$ samples were layered over $5 \mathrm{ml}$ linear sucrose gradients (33 to $68 \% \mathrm{w} / \mathrm{v}$ ) and centrifuged for $4 \mathrm{~h}$ at $300,000 \times \mathrm{g}$ in an Spinco SW 50.1 rotor. Fractions $(0.1 \mathrm{ml})$ were collected by bottom-puncture and assayed for RNA-directed DNA polymerase. Densities were calculated from the refractive indices of the gradient fractions.

The RNA-directed DNA polymerase assay for intracisternal A-particles was as described by Yang et al. [33]. Briefly, gradient fractions from normal and diabetic samples were assayed for polymerase activity in a reaction buffer $(100 \mu$ linal volume) consisting of $50 \mathrm{mmol} / \mathrm{l}$ tris- $\mathrm{HCl}$, $\mathrm{pH} 8.1 ; 10 \mathrm{mmol} / \mathrm{l} \mathrm{Mg}$ acetate; $3 \mathrm{mmol} / \mathrm{l}$ dithiothreitol; $75 \mathrm{mmol} / 1 \mathrm{KCl} ; 0.1 \mathrm{~g} / 100 \mathrm{ml}$ Triton X-100; $20 \mu \mathrm{l}$ of sample. After $10 \mathrm{~min}$ at $4^{\circ} \mathrm{C}$, a template primer [0.02 absorbance units at $260 \mathrm{~m} \mu$ of polyriboadenylate - oligodeoxythymidylate 12-18 (synthetic template-primer, Collaborative Research, Waltham, Mass.)], and $6 \mu \mathrm{mol} / 1$ [methyl- $\left.{ }^{3} \mathrm{H}\right]$ thymidine $5^{\prime}$-triphosphate $\left(6600\right.$ c.p.m. ${ }^{-1}$ pmol $\left.^{-1}\right)$ was added to make the final reaction mixture. The reaction was carried out for $60 \mathrm{~min}$ at $37^{\circ} \mathrm{C}$ and was terminated by the addition of yeast t-RNA $(100 \mu \mathrm{g} / \mathrm{ml})$ and $3 \mathrm{ml}$ of $10 \mathrm{~g} / 100 \mathrm{ml}$ trichloroacetic acid with sodium pyrophosphate $(20 \mu \mathrm{mol} / \mathrm{l})$. Results are expressed as c.p.m. [methyl ${ }^{3} \mathrm{H}$ ]thymidine $5^{\prime}$-monophosphate incorporated into acid-insoluble product minus counts in reactions without synthetic template-primer.

Since type C RNA-directed DNA polymerase shows optimal activity in the presence of $\mathrm{Mn}^{++}$, and not $\mathrm{Mg}^{++}$ion as a cofactor, these same gradient fractions could be screened for type $C$ enzyme by substituting $0.6 \mathrm{mmol} / 1 \mathrm{Mn}$ acetate for $\mathrm{Mg}$ acetate in the assay mixture described above. Homogenates of whole pancreas were also tested for the presence of type $\mathrm{C}$ virus by serological screening for $\mathrm{p} 30$, a major structural protein of the virus coat with a molecular weight of 30,000 daltons. These assays were kindly performed by Mr. Roy Trimmer (National Cancer Institute, Bethesda, Md.) using a standard complement fixation test [14].

To confirm that the enzyme activity was due to a viral polymerase and not to a contaminating cellular DNA polymerase, the presence of RNA-directed DNA polymerase in gradient fractions was assayed for in an endogenous enzyme assay. In the viral endogenous assay, the synthetic template-primer is deleted for the enzyme is able to transcribe viral RNA. The endogenous assay, unlike the synthetic template-primer directed assay, required the presence of deoxyadenine $5^{\prime}$-triphosphate, deoxycytosine 5'triphosphate, and deoxyguanosine 5 -triphosphate at a final concentration of $8 \times 10^{-5} \mathrm{~mol} / \mathrm{l}$ in addition to [methyl ${ }^{3} \mathrm{H}$ ] thymidine $5^{\prime}$-triphosphate. The endogenous assay was performed in the assay mixture described above. To demonstrate that nucleotite polymerization was dependent upon endogenous template, duplicate samples were pretreated with bovine pancreatic ribonuclease $\mathrm{A}$ type III (100 Kunitz units/mg, Sigma, St. Louis, Mo.) at a concentration of $10 \mu \mathrm{g} / \mathrm{ml}$ for $2 \mathrm{hr}$ at $37^{\circ} \mathrm{C}$.

\section{Cell Culture}

Pancreases from equal numbers of 4-7 day postnatal mutant and control mice (usually 4-8 per group) were excised aseptically, rinsed in Hanks' balanced salt solution, $\mathrm{pH} 7.2$, (HBSS) and then minced finely in HBSS containing $2 \mathrm{mg} / \mathrm{ml}$ collagenase (type IV, 310 units/mg, Worthington Biochemicals, Freehold, N. J.). The pancreases were then transferred to a $12 \mathrm{ml}$ conical plastic centrifuge tube in a final volume of $0.5 \mathrm{ml}$ enzyme solution per pancreas. Digestion proceeded for $10 \mathrm{~min}$ at $37^{\circ} \mathrm{C}$ with constant shearing in and out of siliconised Pasteur pipettes. The cells were centrifuged at $150 \times \mathrm{g}$ for $2 \mathrm{~min}$, and the cell pellets were washed once in Hank's solution and once in modified Eagle's minimum essential medium [MEM (GIBCO, Grand Island, N. Y.) supplemented with $15 \mathrm{mmol} / 1$ HEPES, $0.2 \mathrm{mg} / \mathrm{ml}$ bovine serum albumin (BSA, Sigma Chemicals, St. Louis, Mo.), and 100 units $/ \mathrm{ml}$ penicillin and $100 \mu \mathrm{g} / \mathrm{ml}$ streptomycin]. Medium $\mathrm{pH}$ was 7.2 . This medium had a glucose concentration of $5.5 \mathrm{mmol} / 1$ and was considered as low glucose medium in these studies. The washed cell pellets were then sheared in and out of a Pasteur pipete for $10 \mathrm{~min}$ at $37^{\circ} \mathrm{C}$ in $4.5 \mathrm{ml}$ of a $1: 1: 1: 1$ mixture of $0.35 \mathrm{~g} / 100 \mathrm{ml}$ collagenase, $0.10 \mathrm{~g} / 100 \mathrm{ml}$ hyaluronidase (type I, $460 \mathrm{NF}$ units $/ \mathrm{mg}$, Sigma Chemicals, St. Louis, Mo.), $0.5 \mathrm{~g} / 100 \mathrm{ml} \mathrm{BSA}$, and $0.25 \mathrm{~g} / 100 \mathrm{ml}$ trypsin (Nutritional Biochemicals, 1:250). These components 
were prepared in $\mathrm{Ca}^{++}-\mathrm{Mg}^{++}$-free HBSS. Two $\mathrm{ml}$ of complement-inactivated $\left(30 \mathrm{~min}, 56^{\circ} \mathrm{C}\right.$ ), dialysed, fetal bovine serum was added at the end of the digestion period; cells were centrifuged, washed twice in HBSS and once in modified MEM, and then inoculated into $25 \mathrm{~cm}^{2}$ plastic tissue culture flasks in $5.0 \mathrm{ml}$ of modified MEM with $16.5 \mathrm{mmol} / \mathrm{l}$ glucose and $10 \%$ dialysed fetal calf serum. After $4-5 \mathrm{~h}$ of incubation, unattached epithelioid cells were decanted, rinsed once in $\mathrm{Ca}^{++}-\mathrm{Mg}^{++}$-free HBSS, and then vigorously mixed in $4.0 \mathrm{ml}$ of $0.5 \mathrm{mmol} / 1$ EGTA in $\mathrm{Ca}^{++}-\mathrm{Mg}^{++}$free HBSS for $5 \mathrm{~min}$. This suspension was then layered onto discontinuous Ficoll gradients consisting of $2.0 \mathrm{ml}$ of $25 \%$ and $2.0 \mathrm{ml}$ of $18 \%$ Ficoll (Nyegaard and Co., Oslo, Norway) in HBSS with $15 \mathrm{mmol} / \mathrm{l} \mathrm{HEPES}$. The gradients were centrifuged at approximately $300 \times \mathrm{g}$ for $4 \mathrm{~min}$ at ambient temperature, and the cell bands at the sample to $18 \%$ Ficoll interface and the $18 \%$ to $25 \%$ interface were collected. Cells were centrifuged out of the Ficoll solutions by dilution in Hank's solution, and after 2 washes, each fraction was inoculated into duplicate $35 \mathrm{~mm}$ diameter plastic Petri dishes (Lux) in $2.0 \mathrm{ml}$ aliquots of $16.5 \mathrm{mmol} / 1$ glucose-containing MEM plus serum. After allowing a 2-3 day period for cell attachment, medium was changed at 2 day intervals, with serum being withdrawn at the first medium change in order to remove selectively non-islet cells, principally exocrine and ductal epithelial cells. MEM containing $5.5 \mathrm{mmol} / 1$ glucose was usually employed from day $4-5$ until day $14-17$, but during this period of culture in serum-free medium, the glucose concentration in some cultures was "flip-flopped" as indicated in Table 1 to assess preservation of the ability of $B$ cells to secrete immunoreactive insulin in response to glucose. Insulin in the medium changes was measured by double-antibody radioimmunoassay [25]. When most non-endocrine cells had lysed in the serum-free MEM between days 7-14, leaving highly-purified islet cell clusters, cultures to be used for ultrastructural analysis of virus induction were refed either $5.5 \mathrm{mmol} / \mathrm{I}$ glucose-containing Dulbecco's minimal essential medium or $16.5 \mathrm{mmol} / 1$ glucose-containing medium, for two medium changes (4 days) prior to fixation for electron microscopy.

Cultures of mouse neuroblastoma (C-1300) cells were kindly provided by Dr. L. P. Kozak of the Jackson Laboratory and were maintained in $5.5 \mathrm{mmol} / \mathrm{l}$ glucose-containing DMEM plus $10 \%$ dialysed fetal bovine serum. Large numbers of intracisternal Aparticles have been documented in this cell line [15], such that these cells could be used as a reference source. A cell harvest from 11 confluent $75 \mathrm{~cm}^{2}$ culture flasks was sonicated for $1 \mathrm{~min}$ (Bronwill Bionsonik II sonifier, microtip, maximum power) in $10 \mathrm{ml}$ of $0.25 \mathrm{~mol} / 1$ sucrose in $50 \mathrm{mmol} / \mathrm{l}$ triethanolamine $\mathrm{HCl}, \mathrm{pH} 7.4$, $5 \mathrm{mmol} / 1 \mathrm{KCl}$, and $5 \mathrm{mmol} / \mathrm{l} \mathrm{MgCl} 2$. Intracisternal A-particles were then purified using the procedure of Kuff et al. [18], including modifications [24].

\section{Electron Microscopy}

Islet cell cultures growing in plastic Petri dishes were fixed for $2 \mathrm{~h}$ in cacodylate-buffered $2 \mathrm{~g} / 100 \mathrm{ml}$ glutaraldehyde $-1 \mathrm{~g} / 100 \mathrm{ml}$ paraformaldehyde, $\mathrm{pH} 7.4$; post-fixed for $1 \mathrm{~h}$ in cacodylate-buffered $1 \mathrm{~g} / 100 \mathrm{ml} \mathrm{OsO}{ }_{4}$ at $4^{\circ} \mathrm{C}$ and then stained with $0.5 \mathrm{~g} / 100 \mathrm{ml}$ uranyl acetate in $0.1 \mathrm{~mol} / \mathrm{l}$ sodium acetate. Cells were dehydrated in situ according to the procedure of Perre and Foncin [28]. At least 5 islet cell clusters per dish were selected for thin-sectioning and fields were scanned for viral particles in a Hitachi HU-11C electron microscope. Sucrose gradient purified fractions of adult pancreatic homogenates were pelleted, fixed, embedded, and screened for the presence of isolated retrovirus particles following the method of Smith and Gehle [31].

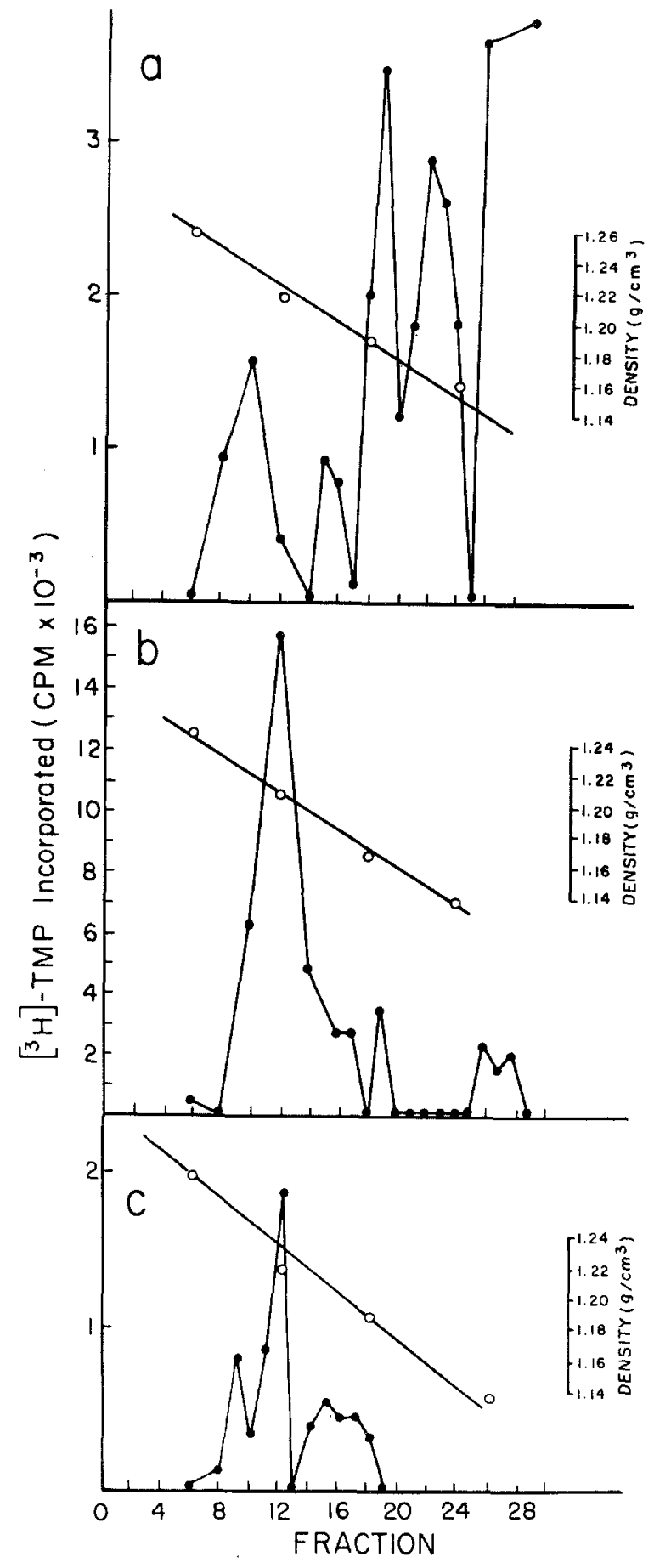

Fig. 1. Sucrose banding of the high-speed cytoplasmic pellet. The high speed extraction pellet from $20 \mathrm{~g}$ of pancreas from both homozygous normal (1a) and diabetic (1b) mice were layered onto a 33 to $68 \%(\mathrm{w} / \mathrm{v})$ sucrose gradient, centrifuged at $300,000 \times$ $\mathrm{g}$ in a SW 50.1 rotor for $4 \mathrm{~h}$ and assayed for RNA-directed DNA polymerase. Fig. $1 \mathrm{c}$ shows the enzyme activity detected in extracts of the neuroblastoma cell line treated in the same way. Activity is expressed as c.p. m. [methyl- ${ }^{3} \mathrm{H}$ ] thymidine $5^{\prime}$-monophosphate $\left(\left[{ }^{3} \mathrm{H}\right]-\mathrm{TMP}\right)$ incorporated per fraction 


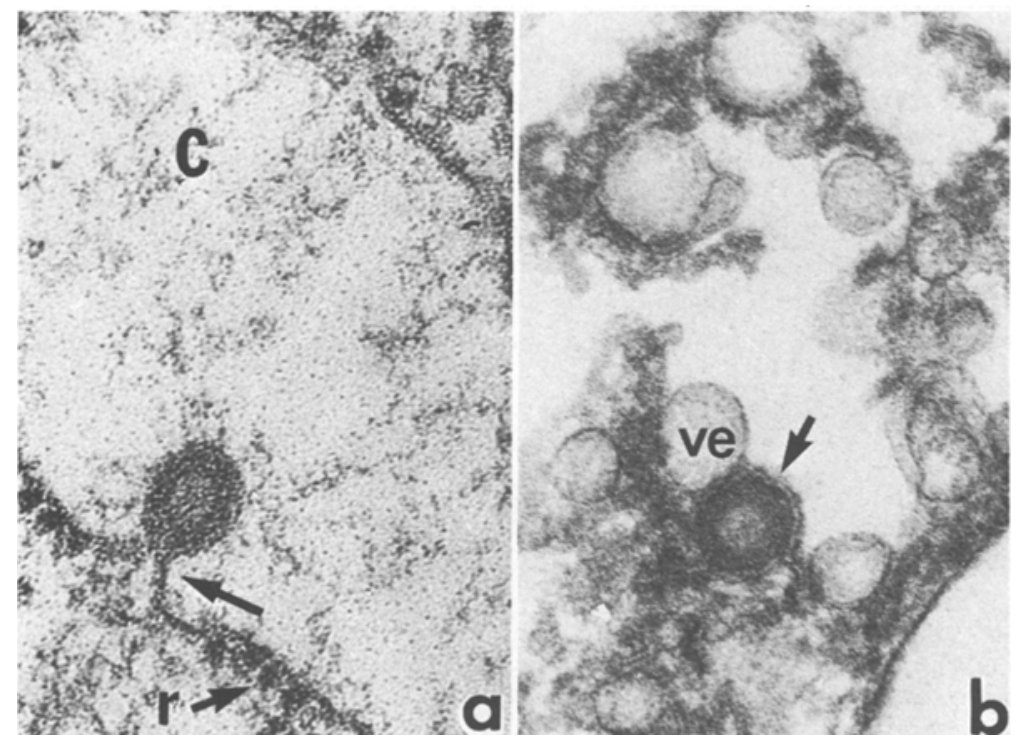

Fig. 2 a and b. Appearance of intracisternal type A particles. a High magnification electron micrograph of an intracisternal type A virus in a beta cell of a 3 month-old $\mathrm{BL} / \mathrm{Ks} \mathrm{db} / \mathrm{db}$ pancreas fixed in situ. An arrow indicates the point at which the particle is budding from the inside surface of the rough endoplasmic reticulum into the cisternal space (c). The particle is comprised of two concentric shells surrounding a relatively electron lucent core. Particle diameter (long axis) is $73 \mathrm{mu} . \times 132,400$. b High magnification electron micrograph of an intracisternal A-particle (arrow) found in fraction 12 of the gradient depicted in Fig. 1b. This fraction (density $=1.21 \mathrm{~g} / \mathrm{cm}^{3}$ ) contained the peak RNA-directed DNA polymerase activity from the extract of $\mathrm{BL} /$ $\mathrm{Ks} \mathrm{db} / \mathrm{db}$ pancreases; ultrastructural analysis of material in this fraction revealed small numbers of completely intact type A-particles surrounded by smooth-surfaced membrane vesicles (ve) and variable amounts of clumped electron dense material. The type A-particle shown has a diameter of $81 \mathrm{~m} \mu$ and is identical in structure to the particle shown in Fig. 2 a. $\times 135,291$

\section{Results}

\section{Particulate RNA-directed DNA Polymerase Activity in Pancreatic Homogenates}

Sucrose density gradient sedimentation profiles of particulate RNA-directed DNA polymerase are shown in Fig. 1. Pancreatic extracts processed from equal (wet weight) amounts of normal tissue (Fig. $1 \mathrm{a}$ ) and $\mathrm{db} / \mathrm{db}$ tissue (Fig. $1 \mathrm{~b}$ ) both exhibited activity in gradient fractions 8-12 (densities ranging between $1.20-1.24 \mathrm{~g} / \mathrm{cm}^{3}$ ). However, the activity of the peak fraction in the extract of normal pancreas (fraction 10, Fig. 1a) was 10-fold lower than that seen in peak fraction 12 (Fig. $1 \mathrm{~b}$ ) of the $\mathrm{db} / \mathrm{db}$ extract $(0.23 \mathrm{pmol} / \mathrm{h}$ versus $2.4 \mathrm{pmol} / \mathrm{h}$ respectively of $\left[\right.$ methyl- $\left.{ }^{3} \mathrm{H}\right]$ thymidine $5^{\prime}$-monophosphate incorporated into trichloroacetic acid-insoluble material). A sedimentation profile similar to that observed in $\mathrm{db} / \mathrm{db}$ pancreatic extracts was produced by intracisternal A-particle-rich C1300 neuroblastoma cells processed as a reference standard (Fig. 1c).

A type A-particle polymerase activity was indicated in the $1.20-1.24 \mathrm{~g} / \mathrm{cm}^{3}$ density fractions inasmuch as [methyl- $\left.{ }^{3} \mathrm{H}\right]$ thymidine $5^{\prime}$-monophosphate incorporation required $\mathrm{Mg}^{++}$but not $\mathrm{Mn}^{++}$at the concentrations tested (data not shown). Further, when the fractions showing peaks of polymerase activity in the presence of synthetic template-primer were assayed in the endogenous (synthetic templateprimer-free) reaction, only peak 10 (Fig. 1a) and peak 12 (Figs. 1b, 1c) were active, albeit at levels 2to 3-fold below that seen with exogenous templateprimer added. This endogenous activity was abolished either in the absence of any of the deoxy- ribonucleoside triphosphates, or when the assay samples were pretreated with pancreatic ribonuclease A. The polymerase activity observed in some fractions, e.g., fraction 22 (Fig. 1a), while falling in a density range expected of type $C$ virus $\left(1.15-1.16 \mathrm{~g} / \mathrm{cm}^{3}\right)$, was only detected with the synthetic template-primer present (i. e., no endogenous activity). The lack of type C-like endogenous activity was correlated with the absence of the type $\mathrm{C}$ group-specific $\mathrm{p} 30$ antigen in whole pancreatic homogenates as determined by complement fixation assay.

The appearance of an intracisternal A-particle budding into a cisterna of rough endoplasmic reticulum of a $B$ cell in a 3 month-old $\mathrm{db} / \mathrm{db}$ pancreas is shown in Fig. 2a. The intracisternal A-particles recovered by centrifuging the polymerase activity peak at $1.21 \mathrm{~g} / \mathrm{cm}^{3}$ exhibited the same morphology of the "virus-like bodies" observed in situ, with two concentric shells surrounding a more electron lucent core. The diameter of the particle shown in Fig. 2b (inset) is approximately $81 \mathrm{~m} \mu$; the particle appears to be completely intact and contains some electron dense material in the core. Complex forms of presumed intracisternal A-particle "buds" were also observed in this fraction. Considerable numbers of smooth-surfaced membranous vesicles were the major contaminants seen. No intact virus particles could be visualized by electron microscopy of the peak fraction of the normal pancreatic isolate (fraction 10, Fig. 1a).

\section{Viral Expression in Cell Culture}

Islet cells as well as large numbers of nonendocrine epithelioid cells attached in clusters of variable 

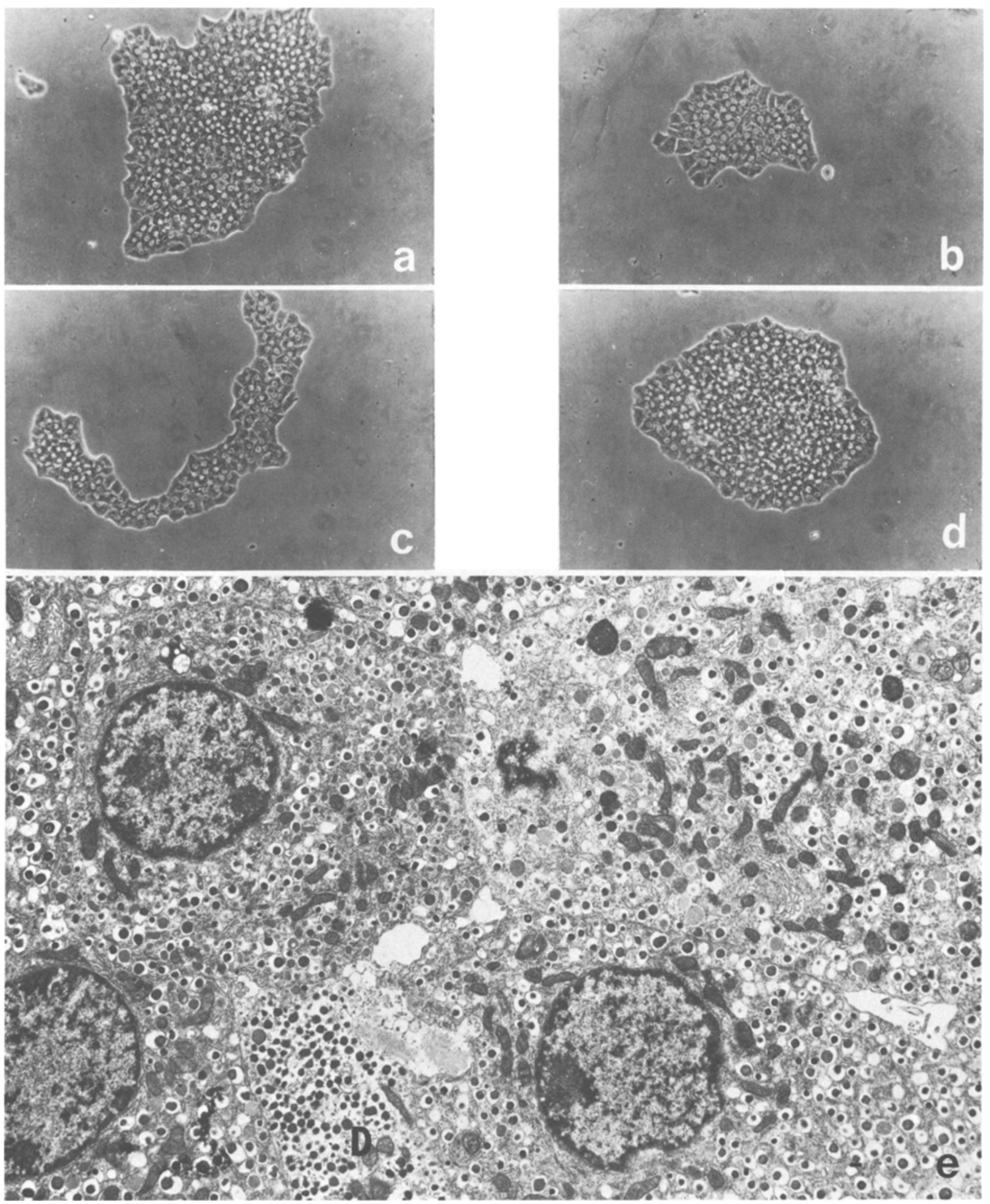

Fig. 3 a-e. Appearance in different media of cultured islet cells from littermate normal (control) and diabetic (mutant) mice. a Control culture, 14 days in vitro, low glucose DMEM during days 11-14, phase optics. $\times 75$. b Control culture, 14 days in vitro, high glucose DMEM during days $11-14$, phase optics. $\times 75$. c Mutant culture, 14 days in vitro, low glucose DMEM during days 11-14, phase optics. $\times 75$. d Mutant culture, 14 days in vitro, high glucose DMEM during days $11-14$, phase optics. $\times 75$. e Electron micrograph of a control culture, 14 days in vitro, low glucose MEM during days 11-14 in vitro. The field shows a single granulated D cell (D) surrounded by wellgranulated beta cells. $\times 5,500$ 

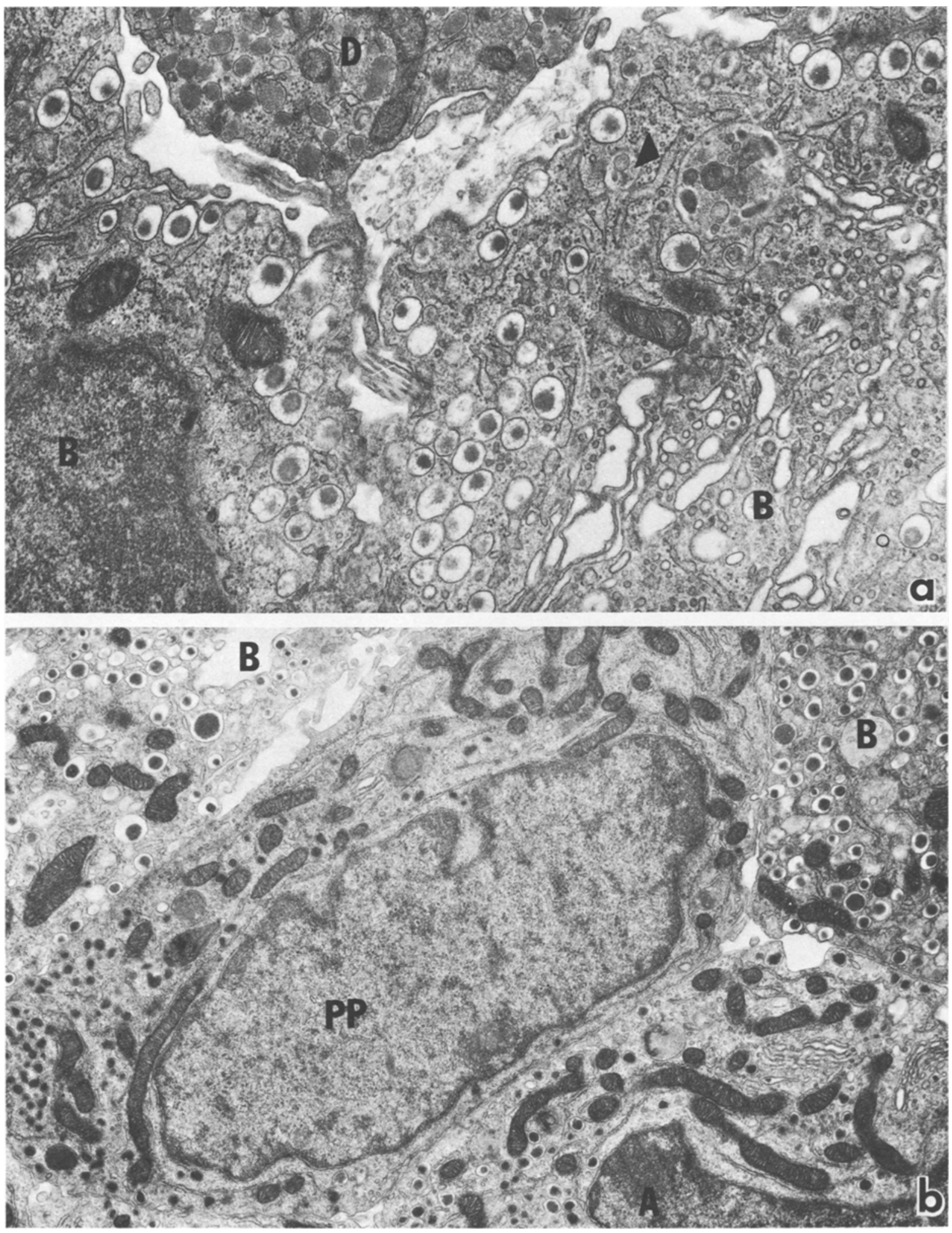

Fig. 4 a and b. Ultrastructural appearance of islet cell cultures in low glucose DMEM during days 14 to 17 in vitro. a Normal (control) culture. Beta cells (B) are well-granulated. A portion of a well-granulated delta cell (D) is also seen. Rough endoplasmic reticulum (arrow) in the beta cells in normal in appearance; no intracisternal A-particles are present in this field and are only rarely encountered in beta cells cultured in this medium. $\times 24,600$. b Diabetic mutant culture. Morphology of the well-granulated beta cells (B) does not differ from that seen in the control cultures. No intracisternal A-particles are present in the field, and occur at the same low incidence as observed for control cultures. A granulated alpha cell (A) and pancreatic polypeptide (PP) cell are shown. The PP cell is differentiated from the other endogrine cell types on the basis of granule size and morphology. Average granule size for $10 \mathrm{PP}$ cell granules chosen at random is $190 \mathrm{~m} \mu$; for the A cell, $229 \mathrm{~m} \mu$, and for the D cell depicted in Fig. $3 \mathrm{a}, 182 \mathrm{~m} \mu . \times 10,500$ 

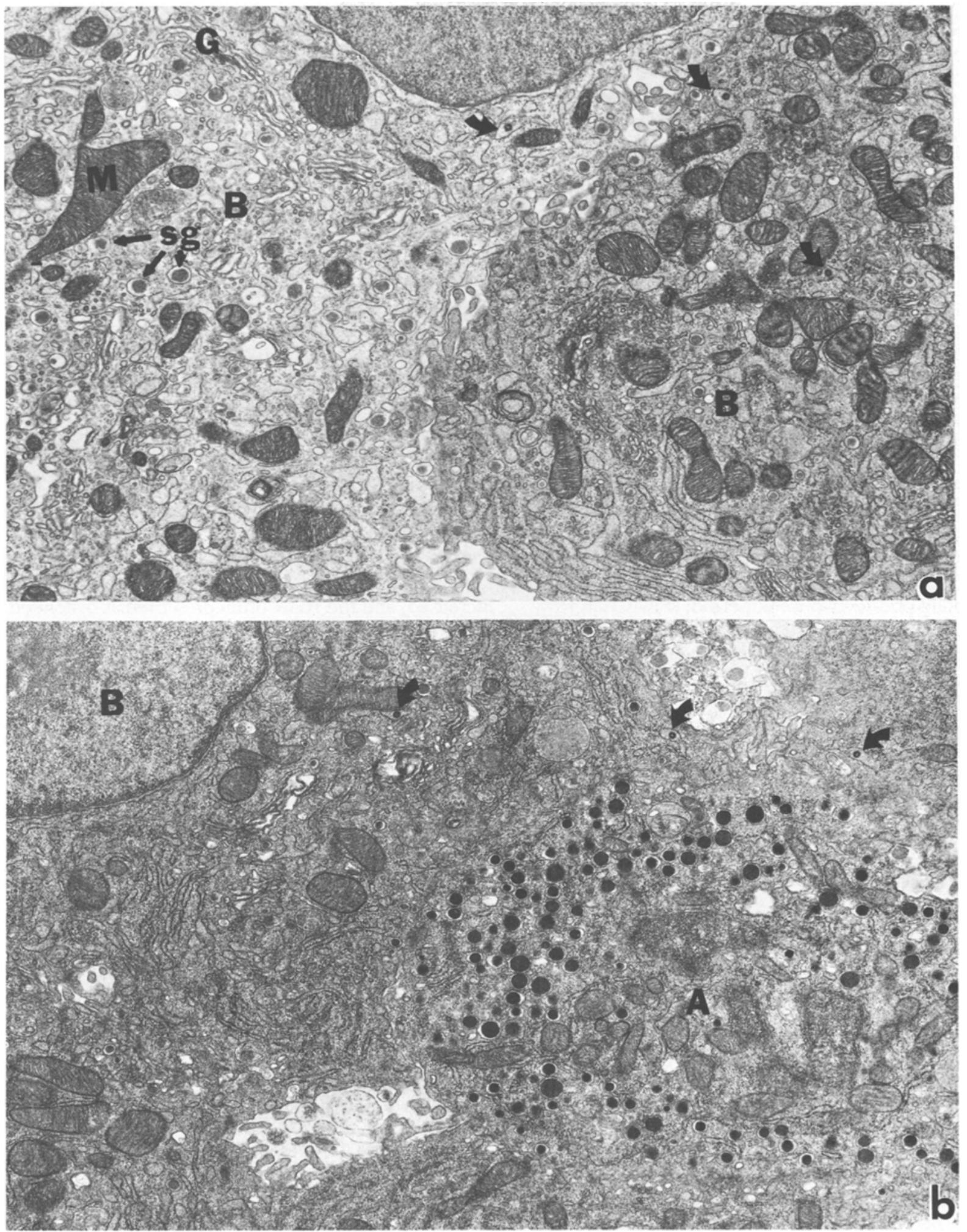

Fig. 5 a and b. Ultrastructural appearance of pancreatic islet cell cultures exposed to high glucose DMEM during days $14-17$ in vitro. a Littermate normal (control) culture. Beta cells (B) in high glucose medium exhibiting different densities of the cytoplasmic ground substance and showing a depletion of secretory granules (sg), well-developed Golgi complexes $(\mathrm{G})$, numerous mitochondria, some of which are enlarged (M), and distended profiles of rough endoplasmic reticulum (RER), some of which contain intracisternal A particles (arrows). This morphology, indicative of hypersecretion, should be contrasted with the comparable culture maintained in low glucose DMEM (Fig. 3 a). $\times 13,900$. b Diabetic (mutant) culture. Beta cells (B) in high glucose medium show same signs of hypersecretory stress as in control culture (Fig. 3 a). In contrast, an alpha cell (A) containing glucagon secretion granules is heavily granulated. Arrows indicate the presence of intracisternal A-particles inside rough endoplasmic reticulum (RER) of the degranulated beta cells. This morphology, indicative of hypersecretion, should be contrasted with the comparable culture maintained in low glucose DMEM (Fig. 3 b). $\times 12,900$ 
Table 1. Insulin release by cultured beta cells from control and mutant mice in response to glucose changes in the culture medium

\begin{tabular}{llrll}
\hline $\begin{array}{l}\text { Culture } \\
\text { interval } \\
\text { (days) }\end{array}$ & Medium & $\begin{array}{l}\text { Glucose } \\
\text { concen- } \\
\text { tration } \\
\text { mmol/1 }\end{array}$ & $\begin{array}{l}\text { Insulin secretion } \\
\text { ng/dish }\end{array}$ \\
\cline { 3 - 5 } & & & Control $^{\mathrm{b}}$ & $\begin{array}{l}\text { Misty } \\
\text { diabetic }\end{array}$ \\
\hline $3-5$ & MEM & 16.5 & 76.8 & 72.0 \\
$5-7$ & MEM & 5.5 & 27.0 & 26.4 \\
$7-9$ & MEM & 16.5 & 86.8 & 58.4 \\
$9-11$ & MEM & 5.5 & 16.2 & 14.7 \\
$11-14$ & DMEM & 5.5 & 29.6 & 21.4 \\
$14-17$ & DMEM & 16.5 & 372.0 & 224.0 \\
\hline
\end{tabular}

a Values represent average for a pair of duplicate cultures each assayed in triplicate

b Control cultures are established from mixed homozygous $(+t /$ $++)$ and heterozygous $(\mathrm{m}+/+\mathrm{db})$ mice from the misty diabetic breeding colony

size during the initial two days of culture in serumcontaining MEM, and when maintained on a simple, nutritionally-limiting medium, did not exhibit extensive monolayer formation. Instead, when deprived of serum at day 2 in vitro and maintained in MEM for an ensuing one-to-two week period, slowly outgrowing islet cell clusters were usually all that remained in primary cultures originally containing numerous granulated exocrine cells, ductal epithelial cells, and some fibroblasts. The morphology of these islet cell clusters at the light microscopic level is illustrated in Fig. 3. No gross morphological differences between islet cells from control or mutant pancreases were apparent (Fig. 3a-d) when cells switched to low glucose DMEM containing $5.5 \mathrm{mmol} / 1$ glucose were compared to those switched to high glucose DMEM containing $16.5 \mathrm{mmol} / \mathrm{l}$ glucose. Data presented in Table 1 show that cultures of B cells from littermate normal and misty diabetic mice retained the ability to respond to glucose stimulation of insulin release. Both types of cultures showed greatest glucose responsiveness when tested in high glucose DMEM.

Electron microscopy (Fig. 3e) of these islet cell clusters maintained in serum-free low glucose MEM or low glucose DMEM at least $48 \mathrm{~h}$ prior to fixation revealed an almost normal distribution of granulated endocrine cell types (80-90\% B cells, the remainder being a mixture of A, PP, and D cells) (Figs. $4 \mathrm{a}, \mathrm{b}$ ). Further, each of these cell types retained its differentiated morphology, showing numerous cell-type specific secretory granules, Golgi complexes, and profiles of rough endoplasmic reticulum (RER) in the cytoplasm. With the exception of an increase in the numbers of secondary lysosomes, the cultured islet cells exhibited normal morphology, again with no differences discernible between cultures from lit- termate normal or pre-diabetic mice. In such cultures maintained in low-glucose media, the appearance of intracisternal A-particles was extremely rare, with most endocrine cells seen in a single thin section being devoid of particles (Fig, 3e, $4 \mathrm{a}, \mathrm{b}$ ). No more than a single type A-particle was ever observed within a cell, and these rare detections occurred with equal frequency in cultures from control or diabetes mice.

Within $48 \mathrm{~h}$ after switching cultures to high glucose DMEM, but not low glucose DMEM, distinctive changes in the ultrastructure of cultured B cells from both normal and diabetes mice were observed. These changes were specific for the B cells and were associated with the hypersecretion of insulin induced by the upward shift in the concentration of glucose and insulinogenic amino acids (Table 1). Many B cells exhibited a massive depletion of secretory $B$ granules (Fig. $5 \mathrm{a}, \mathrm{b}$ ) while the non-B endocrine cell types, such as the A cells, remained granulated (Fig. $5 \mathrm{~b}$ ). Most of the B cells exhibiting extreme degranulation also contained enlarged mitochondria with greatly increased cristael and matrix space. Further, the Golgi and RER in these cells appeared to be increased, and the RER often presented as distended cisternal profiles. These hypersecretion-associated changes induced by exposure to high glucose DMEM in vitro very closely resembled the ultrastructural pathology reported for B cells in situ in the $\mathrm{db} / \mathrm{db}$ mouse with established hyperglycaemia [22].

This resemblance of high glucose-stressed cultured islet cells to $\mathrm{db} / \mathrm{db} B$ cells in situ extended to the detection of intracisternal A-particles in cultured $B$ cells exhibiting hypersecretion morphology. Such cells (at an estimated frequency of $33 \%$ of the total B cells in a field) commonly would contain 1-4 type Aparticles; these structures were always observed within distended profiles of RER and were detected with equal frequency in control and $\mathrm{m} \mathrm{db} / \mathrm{m} \mathrm{db} \mathrm{B}$ cells. Since glucocorticoids have been shown to enhance both C-particle [12] and B-particle [13, 26] induction in cell cultures, hydrocortisone hemisuccinate $\left(10^{-5} \mathrm{~mol} / \mathrm{l}\right)$ or dexamethasone $\left(10^{-6} \mathrm{~mol} / \mathrm{l}\right)$ was included in high glucose DMEM in an attempt to increase the numbers of A-particles per cell section. Such an effect on particle number was not observed at the ultrastructural level.

\section{Discussion}

Previous studies dealing with the isolation and characterization of intracisternal A-particles have capitalized upon the fact that although these particles are only occasionally seen in normal mouse cells dur- 
ing differentiation $[6,7]$, they are present in large numbers in certain murine tumours $[15,18,32]$. These tumours have furnished investigators with between 1 to $20 \mathrm{~g}$ (wet weight) of starting material for their purification procedures. The present study has been limited insofar as methodology for virus purification from large quantities of type A-particle-rich neoplastic tissue had to be adapted to small amounts of non-neoplastic pancreatic tissue. In the present study, only $1-2 \mathrm{~g}$ (wet weight) quantities of fresh pancreas from $\mathrm{db} / \mathrm{db}$ mice were available per isolation in any one experiment. Therefore, our study employing whole pancreatic homogenates has of necessity been limited to an analytical and not a preparative scale. Our data from sucrose density gradient analysis show the presence of a small amount of type A-like RNA-directed DNA polymerase activity in extracts from normal mouse pancreas. That this polymerase activity is associated with type A-particles may be inferred from the following observations. Our finding of increased levels of type A-like polymerase activity in pancreatic extracts from hyperglycaemic $\mathrm{BL} / \mathrm{Ks} \mathrm{db} / \mathrm{db}$ mice as compared to normal controls correlates with the morphological detection in situ of "virus-like bodies" in both B cells and acinar cells of pre-terminal diabetic mice [22]. These "virus-like bodies" reveal a typical type A morphology; they bud into cisternae of the RER (cf. Fig. 2a) and do not show the type B and type $C$ characteristic budding from plasma membranes.

Type $\mathrm{C}$ viral information has been detected in the genomes of all mouse strains examined, and exocrine pancreatic cells of some, but not all, inbred mouse strains have been shown to be a favoured site for type C-particle replication [4]. The lack of endogenous type $\mathrm{C}$ viral enzyme activity in any of the density gradient peak fractions from isolates from BL/Ks normal and $\mathrm{db} / \mathrm{db}$ pancreases (Figs. $1 \mathrm{a}, \mathrm{b}$ ) correlated well with the absence of the type $\mathrm{C}$ group-specific p30 antigen in whole pancreatic homogenates. Further, the demonstration by electron microscopy of intact type A-particles from fraction 12 of the $\mathrm{db} /$ $\mathrm{db}$ gradient isolates (Fig. 1b) clearly substantiated the inferences made from the biochemical analysis. In the $\mathrm{db} / \mathrm{db}$ isolates, the peak of polymerase activity corresponded to the expected $1.20-1.24 \mathrm{~g} / \mathrm{cm}^{3}$ density range reported for intracisternal type A-particles $[18,30]$. That these fractions were able to incorporate [methyl- $\left.{ }^{3} \mathrm{H}\right]$ thymidine $5^{\prime}$-monophosphate in the absence of exogenous synthetic template primer established that the presumed type A-particles contained an endogenous viral RNA template which was destroyed by pre-treatment with pancreatic ribonuclease. Since the endogenous activity is relatively specific for RNA-directed DNA polymer- ase, it was assumed that those gradient fractions exhibiting activity only with synthetic templateprimer added probably represented a contaminating cellular DNA polymerase (e. g., fraction 22, Fig. 1 a). Our conclusion that a type A-, and not a type Cparticle is replicating in $\mathrm{BL} / \mathrm{Ks}$ pancreas has been supported by studies of retrovirus induction in the streptozotocin-induced insulitis model developed by Like and Rossini [23]. While insulitis in strain CD-1 mice was shown by ultrastructural and immunocytochemical methods to be accompanied by both type C- and type A-particle induction within B cells, Appel et al. [2] have cited unpublished results showing that in normal $\mathrm{BL} / \mathrm{Ks}$ mice (which respond to the streptozotocin treatment with a severe insulitis), type $A$, but not type $C$ virus is induced.

These studies have raised the possibility that retrovirus expression in B cells could lead to a cellmediated autoimmune response against the islets [2]. However, no evidence demonstrating a causal relationship between endogenous retrovirus expression and $\mathrm{B}$ cell necrosis has yet been established. No cytopathic potential and, in fact, no biological function for the intracisternal A-particle has yet been documented. Nevertheless, the appearance of intracisternal A-particles in B cells of BL/Ks db/db mice prior to islet necrosis and atrophy raises not only the question as to the cytotoxic potential of an endogenous retrovirus, but also the role of the $\mathrm{db}$ gene in viral induction.

No necrosis of $B$ cells and no intracisternal Aparticles in islet cells were detected morphologically when the db gene was studied on the C57BL/6J (BL/ 6) inbred background [16, and E. H. Leiter, unpublished observations]. Unlike the severe diabetes syndrome produced by $\mathrm{db}$ gene expression in $\mathrm{BL} / \mathrm{Ks}$ mice, this mutant gene in $\mathrm{BL} / 6$ presented as a mild diabetes, severe obesity syndrome $[11,16]$. Thus, the pathogenetic changes in islets accompanying the diabetes syndrome in inbred strains of mice are determined by an interaction of unknown genetic modifiers in the background genome with the $\mathrm{db}$ gene [16]. Conceivably, such background modifiers might control genetic loci regulating expression of retrovirus sequences in the genome.

We have addressed the question of whether the $\mathrm{db}$ gene itself is required for enhancement of intracisternal A-particle replication in the B cell, or whether the appearance of these particles represents a secondary cellular response to the abnormal metabolic environment present in a diseased animal. Our analysis of whole pancreatic homogenates very likely reflects viral expression in the acinar cells that comprise the major portion of the organ [5]. Because we could not isolate islets of Langerhans in quantities 
necessary to attempt type A-particle purification and analysis on sucrose density gradients, we were limited to a qualitative ultrastructural analysis of virus induction in purified cultures of islet cell monolayers. Postnatal pancreas was selected for study because of a favourable islet to exocrine ratio, but primarily because islet cells from mutant mice at the prehyperglycaemic stage of the diabetes syndrome were required.

The reponses of long-term cultured B cells from both normoglycaemic and mutant genotypes to the simulated diabetogenic stress $(16.5 \mathrm{mmol} / 1$ glucose $)$ applied directly through the culture milieu, clearly indicated that environmental factors relating to high glucose concentrations, and not the presence of the $\mathrm{db}$ gene in homozygous state, was stimulating intracisternal type A production. Since a similar stimulation of viral synthesis was not observed when cultures were switched to DMEM containing $5.5 \mathrm{mmol} / \mathrm{l}$ instead of $16.5 \mathrm{mmol} / \mathrm{l}$ glucose, the effect was attributed primarily to the glucose and not other metabolites in DMEM not present in MEM, such as pyruvate. The normoglycaemic controls used in the cell culture studies represent a genotypic mixture of approximately $1 / 3$ homozygotes $(++/++)$ and $2 / 3$ heterozygotes $(++/ \mathrm{m} \mathrm{db})$. Consequently, it might be argued that the equivalent enhancement of intracisternal type A expression observed in cultures established from both mutant and normoglycaemic mice represented an expression of the $\mathrm{db}$ gene in the heterozygous state. This possibility is not considered likely because polymerase sedimentation analysis of pancreatic homogenates from known heterozygous mice $(\mathrm{m}+1+\mathrm{db}$ genotypes from the Animal Resources Colony of the Jackson Laboratory) showed the low levels of particle polymerase activity characteristic of homozygous normals (Fig. 1a) and not diabetic (Fig. 1b) animals. The cell culture studies, then, indicate that the $\mathrm{db}$ gene is not required for intracisternal A-particle induction in $\mathrm{BL} / \mathrm{Ks} B$ cells; rather the elevated levels of certain metabolites, particularly glucose, characteristic of diabetes in this strain appear to be necessary. Similarly, most of the pathology seen at the ultrastructural level in situ may well be attributable to the direct effects of high glucose rather than to any $\mathrm{db}$ gene specific expression at the level of the B cell.

The induction of intracisternal A-particles in islet cells cultured in $16.5 \mathrm{mmol} / \mathrm{l}$ glucose-containing media did not appear to produce cytopathic changes, regardless of genotype. Cultures switched directly to high glucose DMEM at the time of the first medium change and kept on this enriched medium continuously contained islet cells that were as viable as the enriched islet cell cultures produced by first starving non-islet cells in low glucose MEM, and then switching to high glucose DMEM 2 or 4 days prior to fixation for electron microscopy.

Composition of the tissue culture medium is known to be crucial for the maintenance of continued $B$ cell viability and function, with glucose being one of the most important variables [1]. In this study, B cell responsiveness to glucose was maintained in cultures from both normal and mutant pancreases. Elevated medium glucose concentration not only induced a "diabetic" morphology specifically in B cells, but also enhanced intracisternal A-particle expression in these cells. This enhancement of viral expression in high glucose DMEM is comparable to the effect of glucose in this same medium in stimulating B-particle (mouse mammary tumour virus, MMTV) expression in a murine mammary tumour cell line $[13,27]$. In this system, maximal stimulation of MMTV in high glucose DMEM occurred when both glucocorticoids and insulin were incorporated into the medium. Fine et al. [13] have cited evidence in the literature for glucose requirements in viral synthesis and have speculated that glucose may play a role at the translational level. Glucose is known to be one of the most important physiological regulators of $\mathrm{B}$ cell metabolism, including cell replication, insulin biosynthesis, and insulin secretion [27]. The influence on intracisternal type A-particle synthesis of islet cell peptides that may be conditioning the culture medium (e. g., insulin, glucagon, somatostatin, pancreatic polypeptide) were not assessed in this study.

Since adult $\mathrm{BL} / \mathrm{Ks} \mathrm{db} / \mathrm{db}$ mice have been shown to contain increased levels of plasma corticosterone [10], and since glucocorticoid administration can enhance $\mathrm{C}$ - and B-particle expression $[12,13]$, the ability of hydrocortisone and dexamethasone to enhance IAP production in high glucose DMEM was examined. The apparent insensitivity of type A particle synthesis to glucocorticoids found in this system is consistent with the similar negative findings of Kuff, Lueders, Orenstein, and Wilson [20] using cultured mouse neuroblastoma cells. It would appear, therefore, that pancreatic intracisternal type A production is under separate regulatory controls than are the other types of retroviruses, and thus are unlikely to be precursors of $\mathrm{C}$-particles.

Acknowledgements. The authors gratefully acknowledge the skilled technical assistance of Tom Franceschini, Sue Cook, Sandra Rodick, Robert Reuther and Barbara Lee. We thank Drs. John J. Eppig and Hans Meier for their interest and help.

This research was supported in part by research grants $\mathrm{AM}$ 17631, contract NO1CP33255 from the Division of Cancer Causes and Prevention, National Cancer Institute, and a grant from the Juvenile Diabetes Foundation. 
The Jackson Laboratory is fully accredited by The American Association for Accreditation of Laboratory Animal Care.

\section{References}

1. Andersson, A.: Isolated mouse pancreatic islets in culture: effects of serum and different culture media on the insulin production of the islet. Diabetologia 14, 397-404 (1978)

2. Appel, M. A., Rossini, A. A., Williams, R. M., Like, A. A.: Viral studies in streptozotocin-induced pancreatic insulitis. Diabetologia 15, 327-336 (1978)

3. Bernhard, W.: Oncornaviruses. 2. Type A and C virus particles in murine and other mammalian leukemias and sarcomas. In: Ultrastructure of animal viruses and bacteriophages. Dalton, A. J., Haguenau, F. (Eds.), pp. 283-306. New York, London: Academic Press 1973.

4. Boiocchi, M., Della Torre, G., Della Porta, G.: Genetic control of endogenous C-type virus production in pancreatic acinar cells of $\mathrm{C} 57 \mathrm{BL} / \mathrm{He}$ and $\mathrm{C} 57 \mathrm{BL} / 6 \mathrm{~J}$ mice. Proc. Nat1. Acad. Sci. USA 72, 1892-1894 (1975)

5. Boquist, L., Hellman, B., Lernmark, A., Täljedal, I.: Influence of the mutation "diabetes" on insulin release and islet morphology in mice of different genetic backgrounds. J. Cell Biol. 62, 77-89 (1974)

6. Calarco, P.G., Szollosi, D.: Intracisternal A-particles in ova and preimplantation stages of the mouse. Nature 243, 91-93 (1973)

7. Chase, D. G., Pikó, L.: Expression of A- and C-type particles in early mouse embryos. J. Natl. Cancer Inst. 51, 1971-1973 (1973)

8. Coleman, D. L., Hummel, K. P.: Studies with the mutation, diabetes in the mouse. Diabetologia 3, 238-248 (1967)

9. Coleman, D. L., Hummel, K. P.: Hyperinsulinemia in preweaning diabetes $(\mathrm{db})$ mice. Diabetologia 10,607-610 (1974)

10. Coleman, D. L., Burkart, D. L.: Plasma corticosterone concentrations in diabetic $(\mathrm{db})$ mice. Diabetologia 13, 25-26 (1977)

11. Coleman, D. L.: Obese and diabetes: two mutant genes causing diabetes-obesity syndromes in mice. Diabetologia 14, 141-148 (1978)

12. Dunn, C. Y., Aaronson, S. A., Stephenson, J. A.: Interactions of chemical inducers and steroid enhancers of endogenous mouse type C RNA viruses. Virology 66, 579-588 (1975)

13. Fine, D. L., Arthur, L. O., Young, L. J. T.: Cell culture factors influencing in vitro expression of mouse mammary tumor virus. In Vitro 12, 693-701 (1976)

14. Geening, G., Aoki, T., Old, L. J.: Shared viral antigens of mammalian leukaemia viruses. Nature 226, 265-266 (1970)

15. Herrlinger, H., Anzil, A. P., Stavrou, D., Heumann, R., Hamprecht, B., Blinzinger, K.: Intracisternal $A$ and $C$ particles in mouse neurons: a thin section study of normal trigeminal ganglion and C1300 neuroblastoma. J. Natl. Cancer Inst. 55, 1473-1475 (1975)

16. Hummel, K. P., Coleman, D. L., Lane, P. W.: The influence of genetic background on expression of mutations at the diabetes locus in the mouse. I. C57BL/KsJ and $\mathrm{C} 57 \mathrm{BL} / 6 \mathrm{~J}$ strains. Biochem. Genet. 7, 1-13 (1972)

17. Kohno, M., Tanaka, H.: Characterization of an RNA-directed DNA polymerase found in association with murine intradytoplasmic A-particles. J. Virol. 22, 273-280 (1977)
18. Kuff, E. L., Wivel, N. A., Lueders, K. K.: The extraction of intracisternal A-particles from a mouse plasma cell tumor. Cancer Res. 28, 2137-2148 (1968)

19. Kuff, E. L., Lueders, K. K., Ozer, H. L., Wivel, N. A.: Some structural and antigenic properties of intracisternal A-particles occuring in mouse tumors. Proc. Nat1. Acad. Sci. USA 69, 218-222 (1972)

20. Kuff, E. L., Lueders, K. K., Orenstein, J. M., Wilson, S. H.: Differential response of type $C$ and intracisternal type A particle markers in cells treated with iododeoxyruidine and dexamethasone. J. Virol. 19, 709-716 (1976)

21. Like, A. A., Chick, W.L.: Studies in the diabetic mutant mouse. I. Light microscopy and radioautography of pancreatic islets. Diabetologia 6, 207-215 (1970)

22. Like, A. A., Chick, W.L.: Studies in the diabetic mutant mouse. II. Electron microscopy of pancreatic islets. Diabetologia 6, 216-242 (1970)

23. Like, A. A., Rossini, A. A.: Streptozotocin-induced pancreatic insulitis: new model of diabetes mellitus. Science 193, 415-417 (1976)

24. Lueders, K. K., Segal, S., Kuff, E. L.: RNA sequences specifically associated with mouse intracisternal A particles. Cell 11, 83-94 (1977)

25. Morgan, C. R., Lazarow, A. Immunoassay of insulin using a two antibody system. Proc. Soc. Exp. Biol. Med. 110, 29-32 (1962)

26. Nagle, S. C., Fine, D. L.: Demonstration of components of serum-free culture medium effecting maximum in vitro expression of mouse mammary tumor virus. In Vitro 14, 218-226 (1978)

27. Permutt, M. A., Kipnis, D. M.: Insulin biosynthesis and secretion. Fed. Proc. 34, 1549-1555 (1975)

28. Perre, J., Foncin, J.-F.: An embedding method for monolayer cell cultures for light and electron microscopy. Stain Technol. 52, 240-242 (1977)

29. Rossini, A.A., Appel, M.C., Williams, R.M., Like, A.A.: Genetic influence of the streptozotocin-induced insulitis and hyperglycemia. Diabetes 26, 916-920 (1977)

30. Schmidt, J., Pragnell, I. B., Weimann, B. J.: DNA polymerases from intracisternal A-type particles of the mouse plasmacytoma MPCl. Eur. J. Biochem. 73, 493-497 (1977)

31. Smith, K.O., Gehle, W.D.: Pelleting viruses and virusinfected cells for thin-section electron microscopy. Proc. Soc. Exp. Biol. Med. 130, 1117-1119 (1969)

32. Wivel, N. A., Stmith, G.H.: Distribution of intracisternal A particles in a variety of normal and neoplastic mouse tissues. Int. J. Cancer 7, 167-175 (1971)

33. Young, S. S. Calarco, P. C., Wivel, N. R.: Biochemical properties and replication of mouse intracisternal A particles during early embryogenesis. Eur. J. Cancer 11, 131-138 (1975)

Received: December 12, 1978, and in revised form: April 23, 1979

Dr. Edward H. Leiter

The Jackson Laboratory

Bar Harbor, ME 04609

USA 